\title{
ПРОБЛЕМИ ПРАВОВОГО ЗАБЕЗПЕЧЕННЯ ТА РЕАЛІЗАЦІЇ РЕФОРМИ ТЕРИТОРІАЛЬНОЇ ОРГАНІЗАЦІЇ ВЛАДИ В УКРАЇНІ
}

\section{Бодрова I. I.}

\section{ВСТУП}

Проблематика концептуалізації та формування правової політики у сфері територіальної організації влади за останні роки вийшла на якісно новий рівень, який дозволяє говорити, що це - не лише напрям доктринальних досліджень, а й вектор сучасного державно-правового розвитку України. Період системного реформування у сфері державного будівництва та місцевого самоврядування на перший план за ступенем актуальності серед основних напрямів реформ висуває саме правовий. Адже, будучи науково обгрунтованою, поступальною та системною діяльністю з формування ефективного механізму правового регулювання, правова політка покликана забезпечувати оптимізацію правового розвитку держави та ії інститутів.

Одним із центральних об'єктів сучасних системних перетворень $є$ територіальна організація влади. Проблематика оптимізації ії визнається одним із тих основних чинників, які спрямовують розвиток державності. Майбутне України як держави, іiі спроможність до економічного, соціального, культурного розвитку залежать від того, наскільки ефективно будуть вирішені проблеми територіальної структури публічно-владного управління. Безумовно, не всі проблеми в цій сфері мали і мають правовий характер, але можна стверджувати, що правова проблематика територіального устрою завжди посідала особливе місце в політикоправовому розвитку країни, характеризувалася особливою гостротою, а iз часом іiі наукова та практична значущість лише зростає.

На цей час у державі накопичилося багато як теоретичних, так i практичних проблем, які стосуються правових аспектів територіальної організації влади, серед них нереалізованість реформи адміністративнотериторіального устрою як основи архітектоніки нової організаційної моделі органів публічної влади в державі, незавершеність реалізації муніципальної реформи на засадах субсидіарності, повсюдності та спроможності місцевого самоврядування, обмеженість реформи регіонального рівня організації влади в інституційних та функціональних аспектах реалізації. Роботи низки дослідників виявляються перенасиченими політологічною, управлінською, економічною, соціологічною риторикою, тоді як цілісна наукова концепція 
територіальної організації влади, яка б відбивала сучасні вітчизняні реалії та світові тенденції, по суті залишається нерозробленою.

Юридична наука під час опрацювання зазначеної концепції має відігравати вирішальну роль, адже саме в іiі межах виробляється ідеологія права як соціального інституту, опрацьовуються його цілі, функції, принципи, дух і сенс, формуються нові галузі, інститути і норми права, нові юридичні конструкції, поняття, інструменти, прогнозується еволюція юридичних технологій і правового життя ${ }^{1}$. Окремі питання правового регулювання територіальної організації влади в Україні порушувалися в працях багатьох вітчизняних учених-державознавців: В.Б. Авер'янова, Ю.П. Битяка, В.І. Борденюка, Р.А. Калюжного, В.І. Кампа, О.Л. Копиленка, А.Р. Крусян, П.М. Любченка, О.Ю. Лялюка, Н.Р. Нижник, М.О. Пухтинського, С.Г. Серьогіної, П.М. Ткачука, В.М. Шаповала й інших. Аналіз стану правового забезпечення формування та реалізації реформи територіальної організації влади в Україні є завданням даної роботи.

\section{1. Концептуальні основи реформи територіальної організації влади в Україні}

Юридичні погляди і наукові доктрини є найважливішими чинниками вдосконалення правового регулювання територіальної організації влади в Україні, формування спеціального законодавства, оптимізації методології інтерпретації конституційних та законодавчих норм у цій сфері, а також правореалізаційного процесу. Ігнорування розроблень сучасної державознавчої науки, як і недостатня науково-теоретична опрацьованість засад, системно-структурних та процедурно-процесуальних аспектів, відсутність практико-орієнтованих моделей та конструкцій, як слушно зазначає А.П. Гетьман, приречує державно-територіальне будівництво країни на шлях «спроб і помилок» .

Забезпечення концептуалізації теоретичних поглядів та практичних підходів у сфері правового регулювання територіальної організації влади $\epsilon$ одним iз першочергових завдань юридичної науки. Адже концепції загалом завдають високий стандарт законотворчості, що дозволяє визначити прогнозований рівень та якість законопроектної роботи відповідно до сучасних потреб соціально-економічного розвитку країни, сприяють законодавчому забезпеченню проведення державних реформ. На етапі модернізації територіальної організації публічної влади в Україні все більш очевидним стає той факт, що цілеспрямований та комплексний

\footnotetext{
${ }^{1}$ Малько А.В. Теория правовой политики. Москва : Юрлитинформ, 2012. С. 156-157.

2 Гетьман А.П. Концептуальні засади модернізації конституційної моделі територіального устрою України. Вісник Конституційної Асамблеї. 2013. № 1. С. 325.
} 
характер державотворчих перетворень не може бути забезпечений поза чіткою та всебічно обгрунтованою концептуальною основою. Без такої концептуальної визначеності держава ризикує залишитися у вихорі стихійних процесів політичної ситуативності, без необхідних смислових орієнтирів і ефективних правових форм регуляції ${ }^{3}$.

Одним із результатів концептуалізації наукових знань щодо стратегії $\mathrm{i}$ тактики перетворень територіальної організації влади стала Концепція реформування місцевого самоврядування та територіальної організації влади в Україні, схвалена розпорядженням Кабінету Міністрів України № 333-р від 1 квітня 2014 p. ${ }^{4}$ Концепція стала першим за роки незалежності України документом, що заклав науково-методологічну основу цілеспрямованого, системного та комплексного реформування адміністративно-територіального устрою, місцевого самоврядування й організації державної влади на територіальному рівні. Загалом цей документ дістав схвальну оцінку та підтримку наукового середовища ${ }^{5}$.

Варто зазначити, що до цього часу неодноразово різними вищими органами державної влади здійснювалися спроби визначити стратегічні пріоритети в даній сфері. Зокрема, ще в липні 1998 р. Президентом України схвалена Концепція адміністративної реформи, у травні 2001 р. затверджена Концепція державної регіональної політики, у серпні Програма державної підтримки розвитку місцевого самоврядування в Україні. Верховною Радою України 1999 р. схвалена Концепція сталого розвитку населених пунктів, а наступними кроками парламенту стало ухвалення законів України «Про Генеральну схему планування території України», «Про стимулювання розвитку регіонів України». Кабінетом Міністрів України 2006 р. затверджена Державна стратегія регіонального розвитку на період до 2015 р., а 2009 р. схвалена Концепція реформи місцевого самоврядування. Але ці документи мали здебільшого вузький характер, будучи зорієнтованими на окремі аспекти територіального розвитку. Залишившись здебільшого декларативними актами, вони не надали відчутного поштовху в напрямі реформ.

Водночас правова доктрина у сфері територіальної організації влади демонструвала істотне відставання від державотворчих процесів, які йшли часто експериментальним шляхом, через запозичення тих чи інших

\footnotetext{
3 Нерсесянц В.С. Процессы универсализации права и государства в глобализирующемся мире. Государство и право. 2005. № 5. С. 39.

${ }^{4}$ Про схвалення Концепції реформування місцевого самоврядування та територіальної організації влади в Україні : розпорядження Кабінету Мінстрів України № 333-р від 1 квітня 2014 р. Офіųійний вісник Украӥни. 2014. № 30. Ст. 18.

${ }^{5}$ Шемшученко Ю.С., Батанов О.В., Крусян А.Р. Конституційний процес в Україні та світовий досвід конституціоналізму. Київ : Юридична думка. 2014. С. 210.
} 
інститутів та механізмів іноземних держав. Перманентні експерименти щодо реформування інститутів територіальної організації влади на місцях, які здійснювалися на основі емпіричного досвіду протягом 90-х 2000-х pp., бажаних результатів не дали. За цей час у державі накопичилася значна кількість правових, інституційних, функціональнокомпетенційних, процедурно-процесуальних проблем. Виправлення наявних недоліків потребувало переходу до системних трансформаційних змін.

Концепцією реформування місцевого самоврядування та територіальної організації влади в Україні на основі аналізу наявних проблем та недоліків системи територіальної організації влади були визначені шляхи і способи ïх вирішення через поетапне проведення реформи як системи місцевого самоврядування, державного управління на територіальному рівні, так $\mathrm{i}$ адміністративно-територіального устрою. В основу Концепції покладені національні здобутки державного та муніципального будівництва та сучасні ідеї конституціоналізму - децентралізації влади, регіоналізму, демократизації публічного управління. Це - ті цінності і надбання, які $є$ важливими для розвитку не лише нашої держави.

Аналіз трансформаційних процесів на європейському просторі дає підстави вважати, що саме вони визначають керівні ідеї державного розвитку сучасності. Хоча у XXI ст. країни Європи увійшли зі значним досвідом реформ територіальної організації влади i сформованою архітектонікою адміністративно-територіального устрою, новітня хвиля перетворень охопила Європу з початком XXI ст. Такі реформи покликані, заклавши необхідну територіальну основу, забезпечити зміни в розподілі функцій i компетенції між органами публічної влади, оновлення організаційної моделі територіального управління, а також удосконалення міжбюджетних відносин ${ }^{6}$. Подальша децентралізація влади для країн, побудованих за моделлю національної державності, - нагальна необхідність, умова існування такої моделі.

Концепція реформування місцевого самоврядування і територіальної організації влади в Україні характеризується високим ступенем системності, передбачаючи побудову цілісної моделі територіальної організації влади. Уперше розробники системно підійшли до проблем удосконалення системно-структурної організації публічної влади та проблем адміністративно-територіального устрою. Адже очевидно, що без вирішення останніх докорінним чином модернізувати владний механізм неможливо. В умовах підвищення й ускладнення ролі сучасної держави

\footnotetext{
6 Бодрова I.I., Любченко П.М. Свропейський досвід удосконалення місцевого самоврядування. Харків : Оберіг, 2012. С. 9-10.
} 
відбувається переосмислення значення такого устрою - він має забезпечувати поєднання необхідного з погляду загальнодержавних цілей та завдань розвитку рівня концентрації ресурсного потенціалу, публічновладного механізму зі створенням просторових меж самодостатньої активності окремих соціально-територіальних спільнот.

Реалізація системного та концептуального бачення оновленої моделі територіальної організації влади, зокрема адміністративно-територіального устрою держави та системно-структурної організації публічної влади на регіональному і місцевому рівнях публічної влади, потребвала оновлення конституційно-правового регулювання.

Законопроект «Про внесення змін до Конституції України (щодо децентралізації влади)» (реєстр. № 2217а) насамперед передбачив уточнення конституційно-правових засад територіальної організації влади ${ }^{7}$. Закріплення на найвищому законодавчому рівні принципів, окреслених Європейською хартією місцевого самоврядування, - децентралізації, повсюдності та спроможності місцевого самоврядування - 3 наступним запровадженням законодавчого механізму їх реалізації мало: по-перше, дозволити зробити кроки щодо посилення матеріально-фінансової самостійності територіальних громад; по-друге, вимагати здійснення місцевого самоврядування на територіях, відмежованих одна від одної; по-трете, гарантувати здійснення місцевого самоврядування на всій території країни без будь-яких обмежень, на території не лише населених пунктів, але й на прилеглих до них територіях; по-четверте, дозволити відповідно до європейських стандартів раціоналізувати розподіл компетенції між рівнями територіальної організації публічної влади, виключивши значне число потенційних публічно-владних конфліктів; по-п'яте, забезпечити формування повноцінної організаційної моделі муніципальної влади на районному та регіональному рівнях; пошосте, вдосконалити систему державного управління на місцевому рівні; посьоме, сформувати конституційно-правові основи державного нагляду за законністю діяльності органів та посадових осіб місцевого самоврядування; а також забезпечити усталеність і комплексність територіального розвитку.

Оновлення конституційно-правової моделі територіальної організації влади, безумовно, потребує синхронізації із законодавчим забезпеченням деталізації конституційно-правового регулювання та реалізації положень Основного закону. Конституція України має виступати фундаментом для формування якісно нового законодавства у сфері територіальної організації влади. Формування i реалізація конституційно-правової політики передбачає, як слушно зауважує А.Р. Крусян, послідовну,

\footnotetext{
${ }^{7}$ Про внесення змін до Конституції України (щодо децентралізації влади) : проект закону України від 1 липня 2015 р. № 2217. URL: http://w1.c1.rada.gov.ua/pls/zweb2/webproc4_1?pf3511=55812.
} 
структуровану систему конституційного законодавства, що вирізняється оптимальним поєднанням стабільності й гнучкості, що можливо лише за чіткого визначення предмета регулювання 3 боку найважливішого нормативного акта в цій системі після Конституції - конституційного закону ${ }^{8}$. Так, конституційним законопроектом пропонувалося безпосередньо закріпити необхідність законодавчого врегулювання цілої низки відносин у сфері адміністративно-територіального устрою України, організації та здійснення місцевого самоврядування й управління на місцевому рівні.

Проте нереалізованість конституційної реформи фактично призвела до істотного гальмування законодавчого забезпечення реформи територіальної організації влади. Якщо звернутися до Плану законодавчого забезпечення реформ в Україні, схваленого Верховною Радою України ще 4 червня 2015 р., p. 3 «Регіональна політика та децентралізація», то з 11 законопроектів на сьогоднішній день ухвалено лише один 9

Маємо зауважити, що Концепція реформування місцевого самоврядування та територіальної організації влади в Україні відіграла важливу політикоправову роль документа, на базі якого вибудовуються сучасні механізми муніципальної, регіональної та секторальних реформ у державі. Концепція стала першим за роки незалежності України документом, що заклав науковометодологічну основу цілеспрямованого, системного та комплексного реформування адміністративно-територіального устрою, місцевого самоврядування й організації державної влади на місцевому рівні.

Будучи документом не декларативного характеру, а орієнтованим на практичну реалізацію, Концепція визначила поетапні заходи чотирирічного періоду реалізації. Встановлений строк виконання їх уже завершений, у результаті, із 13 комплексних заходів реформування місцевого самоврядування та територіальної організації влади реалізовано лише 4. I це ставить завдання підбиття проміжних підсумків здійснених на основі Концепції перетворень та визначення пріоритетів подальшого розвитку.

\section{2. Питання правового забезпечення муніципальної реформи в Україні}

Уперше Концепція реформування місцевого самоврядування та територіальної організації влади в Україні проголосила як один із напрямів реформ імплементацію найважливіших принципів місцевого самоврядування, визначених Європейською хартією місцевого самоврядування, - повсюдність місцевого самоврядування, його правову,

\footnotetext{
${ }^{8}$ Крусян А.Р. Сучасний український конституціоналізм. Київ : Юрінкомінтер, 2010. С. 315.

${ }^{9}$ Про План законодавчого забезпечення реформ в Україні : постанова Верховної Ради України від 4 червня 2015 р. № 509-VIII. Відомості Верховної Ради Украӥни. 2015. № 31. Ст. 297.
} 
організаційну та матеріально-фінансову спроможність, субсидіарність, забезпечення доступності та належної якості публічних послуг ${ }^{10}$. Тому насамперед рішучі та послідовні кроки були зроблені на шляху реформування базового рівня місцевого самоврядування, i це цілком обгрунтовано. Адже не можна побудувати міцний будинок територіальної організації влади без міцного фундаменту.

1. Передумовою практичного впровадження реформи територіальної організації влади стало ухвалення 2014 р. Закону України «Про співробітництво територіальних громад» ${ }^{11}$. Незважаючи на прогресивну ідею, закладену в нормах цього Закону, його організаційно-правовим інструментом скористалася відносно невелика кількість територіальних громад - за даними Міністерства регіонального розвитку, будівництва та житлово-комунального господарства України, станом на 28 лютого 2019 р. укладено тільки 354 таких договорів ${ }^{12}$.

2. Процес запровадження реформи перейшов в активну фазу 3 ухваленням 5 лютого 2015 р. Закону України «Про добровільне об'єднання територіальних громад» ${ }^{13}$. Позитивний ефект від цього напряму реформи $\epsilon$ очевидним - це формування станом на 28 лютого 2019 р. 806 об'єднаних територіальних громад, крім того, 74 ще чекають на ухвалення відповідних рішень. Високим є рівень активності об'єднаних громад у розробленні інфраструктурних проектів: майже всі об'єднані територіальні громади подали такі проекти, а обсяг інфраструктурної субвенції становить 2,1 млрд грн ${ }^{14}$.

3. Одночасно проведена реформа бюджетно-фінансової децентралізації, правовому забезпеченню якої слугували закони про внесення змін та доповнень до бюджетного та податкового законодавства України, а також низка підзаконних актів. 3 початку ії доходи місцевих бюджетів стрімко зростають: якщо 2014 р. їхній обсяг становив 68,6 млрд грн, то за п’ять років, як очікується, вони зростуть майже в 4 рази та за підсумками 2019 р. становитимуть 267 млрд грн. Про фінансову спроможність місцевих бюджетів свідчать залишки коштів на казначейських рахунках місцевих бюджетів: станом на 1 січня 2019 р. залишки коштів усіх місцевих бюджетів України становили 49 млрд грн, із яких на рахунках загального

\footnotetext{
${ }^{10}$ Європейська хартія місцевого самоврядування : міжнародний документ від 15 жовтня 1985 p. URL: http://zakon2.rada.gov.ua/laws/show/ 994_036.

11 Про співробітництво територіальних громад : Закон України від 17 червня 2014 р. № 1508-VII. Відомості Верховної Ради Украӥни. 2014. № 34. Ст. 1167.

12 Реєстр договорів про співробітництво територіальних громад. URL: http://www.minregion.gov.ua/ wp-content/uploads/2019/02/reestr-27.02.2019.pdf

13 Про добровільне об'єднання територіальних громад : Закон України від 5 лютого 2015 р. № 157-VIII. Відомості Верховної Ради Украӥни. 2015. № 13. Ст. 91.

${ }^{14}$ Об’єднані територіальні громади. URL: decentralization.gov.ua/gromada.
} 
фонду - 31,8 млрд грн. Держава також збільшила обсяги надання бюджетної підтримки місцевим органам влади на розвиток громад та розбудову інфраструктури. Так, якщо 2014 р. було регіонам із державного бюджету на підтримку соціально-економічного розвитку передбачено лише 0,5 млрд грн, то 2018 р. обсяг коштів на реалізацію інфраструктурних проектів становив 19,37 млрд грн, а на 2019 р. передбачено 20,75 млрд грн, що в 41,5 рази більше, ніж було 2014 p. ${ }^{15}$ Завдячуючи фінансовій децентралізації, громади отримали значні фінансові преференції та можливість спрямовувати додаткові кошти, яких раніше не бачили, на розвиток інфраструктури та благоустрій населених пунктів (ремонт доріг, освітлення вулиць, ремонт закладів охорони здоров'я та освіти тощо).

4. У межах адміністративного напряму реформи територіальної організації влади розпочатий процес системної модернізації галузевого управління зі скороченням числа територіальних органів центральних органів виконавчої влади, забезпеченням функціональної спеціалізації та розмежуванням предметної підвідомчості цих органів.

5. На основі визначеного Концепцією розподілу сфер предметної підвідомчості здійснюється системна робота 3 перерозподілу функцій та повноважень за вертикаллю територіальної організації влади на засадах субсидіарності та децентралізації, спрямована на побудову цілісної функціональної моделі організації влади. Чи не найбільшим здобутком реформ стала передача повноважень та ресурсів на місця, завдяки чому адміністративні послуги вдалося наблизити до людей, відкрити центри надання адміністративних послуг, перейти на електронний документообіг у цій сфері. Наближення послуг до громадян та їхня доступність забезпечується формуванням мережі названих центрів, яких в Україні на сьогодні налічується майже 1000.

Але очевидними $є$ й ті складнощі, які гальмують подальше впровадження та поширення реформ.

По-перше, склалася ситуація, коли муніципальна практика йде попереду ухвалення законів. Саме вона виявляє багато прогалин та колізій правового регулювання, законодавче усунення яких значно відстає. Цілком очевидною є така тенденція: за високої активності законопроектної роботи результативність законодавчого забезпечення відповідних реформ $\epsilon$ недостатньо високою. У зв'язку із цим потребує активізації взаємодія всеукраїнських асоціацій органів місцевого самоврядування iз профільними парламентськими комітетами, депутатським фракціями, а

\footnotetext{
15 Фінансова децентралізація: експерти розповіли про результати 2018 р. та перспективи 2019 p. URL: https://decentralization.gov.ua/news/10670?fbclid=IwAR0F89YRsn9N_Elc_wJAU86V9gkyGhO8Ly_YvnG9nuQytlcAQa_QLEShig.
} 
також посилення ролі консультативно-дорадчих структур iз питань місцевого самоврядування в законопроектній діяльності вищих та центральних органів виконавчої влади.

Пожвавлення законодавчого забезпечення реформи територіальної організації влади сприятиме формуванню ефективного організаційноправового механізму іiі здійснення та підвищенню легітимності відповідних державно-правових рішень. Останнє набуває особливого значення на сучасному етапі правового забезпечення реформ. Так, дещо дивно, що імплементація у вітчизняну державно-правову практику одного 3 основоположних європейських стандартів організації муніципальної влади, на яку так довго чекала муніципальна спільнота, а саме повсюдності місцевого самоврядування, забезпечена не відповідними змінами та доповненнями до законів України (Земельний кодекс України, закони України «Про добровільне об’єднання територіальних громад», «Про місцеве самоврядування в Україні» та ін.), а урядовим рішенням, навіть більше, рішенням ненормативного характеру ${ }^{16}$. Фактична передача повноважень органам місцевого самоврядування розпорядженням Кабінету Міністрів України без відповідних законодавчих змін чинних законів породжуватиме питання легітимності муніципальних рішень, відповідності вимогам ч. 2 ст. 19 Конституції України щодо діяльності виключно в межах повноважень та способом, визначеним Конституцією та законами України.

По-друге, перерозподіл владних повноважень між центральними органами державної влади й органами місцевого самоврядування здебільшого відбувається на засадах не передачі повноважень у власну компетенцію місцевого самоврядування 3 наданням у комунальну власність відповідних ресурсів, а шляхом їх делегування зі збереженням державного характеру таких повноважень та державного контролю за їх виконанням. Водночас, як i раніше, гостро стоїть питання виконання державних зобов'язань щодо матеріально-фінансового забезпечення їх реалізації муніципальними органами. У зв'язку із чим цілком слушно запропоновано законодавчим шляхом забезпечити здійснення об'єктивного і повного розрахунку обсягів трансфертного забезпечення делегованих повноважень на основі державних стандартів і нормативів соціальних та адміністративних послуг; встановлення методик розрахунку фінансового забезпечення окремих делегованих повноважень; організацію та здійснення постійного моніторингу повноти та своєчасності матеріально-фінансового забезпечення, його коригування 3 урахуванням економічної та громадсько-політичної ситуації в країні

\footnotetext{
16 Питання передачі земельних ділянок сільськогосподарського призначення державної власності у комунальну власність об’єднаних територіальних громад : розпорядження Кабінету Міністрів України від 31 січня 2018 р. № 60-p. URL: https://zakon.rada.gov.ua/laws/show/60-2018-\%D1\%80.
} 
(зокрема, збільшення видатків на соціальне й адміністративне обслуговування внутрішньо переміщених осіб); зміцнення засад спільного, державно-муніципального фінансування бюджетних програм; економічне стимулювання ефективного використання наданих державою ресурсів; запровадження методик оцінки ефективності здійснення делегованих повноважень ${ }^{17}$.

По-третє, під час реформування базового рівня місцевого самоврядування дуже важливо не обманути довіру людей. Намагаючись створити правову основу для більш спроможних територіальних громад, законодавець за роки реалізації Концепції реформування місцевого самоврядування та територіальної організації влади в Україні чомусь не приділив належної уваги питанню локальної демократії. Але чи може вважатися дійсно здатною вирішувати власну долю територіальна громада, яка не має ефективних організаційно-правових можливостей для безпосереднього народовладдя? Гадаємо, відповідь очевидна.

Концепцією поставлено завдання щодо розроблення й ухвалення змін до законодавства, що регламентує участь територіальної громади у вирішенні питань місцевого значення. Ідеться про реформування підходів до порядку організації і застосування форм партисипативної демократії на всіх рівнях територіальної організації влади. Відповідні законопроекти розроблено ще 2015 р. (законопроекти № № 2295, 2295a, 2296, 2296a, 2297, 2297a), а також 2017 р. (законопроекти № № 3534, 7297, 7297-1). Сьогодні обговорюються декілька варіантів альтернативних законопроектів, але всі вони ще далекі від ухвалення і практичної реалізації. 3 їх увхаленням пов'язується й імплементація вимог Додаткового протоколу до Європейської хартії місцевого самоврядування про право участі в справах місцевого органу влади ${ }^{18}$.

По-четверте, нереалізованість реформи адміністративно-територіального устрою призводить до того, що значна частка проблем місцевого та регіонального розвитку залишаються не вирішеними. Правова доктрина та правотворча діяльність у сфері адміністративно-територіального устрою демонструють істотне відставання від державотворчих процесів - вони не надають адекватного правового рішення для вирішення проблем у цій сфері. За відсутності законодавчих механізмів вирішення питань адміністративнотериторіального устрою органи публічної влади вимушені використовувати

\footnotetext{
${ }^{17}$ Новак А.О. Конституційно-правове регулювання здійснення органами місцевого самоврядування делегованих повноважень органів виконавчої влади в Україн : дис. ... канд. юрид. наук: 12.00.02. Харків, 2017. С. 169.

18 Додатковий протокол до Європейської хартії місцевого самоврядування про право участі у справах місцевого органу влади. URL: https://zakon.rada.gov.ua/laws/show/994_946.
} 
інші, «опосередковуючі» правові механізми, передбачені земельним законодавством та законодавством про місцеве самоврядування.

Наприклад, неврегульованість матеріально-правових та процедурнопроцесуальних аспектів реорганізації населених пунктів шляхом їх об'єднання сьогодні змушує застосовувати такий механізм, як зміна меж населених пунктів шляхом передачі земель у відання іншої місцевої ради. Він дозволяє вирішити питання «просторового» характеру, але не надає можливості вирішити проблеми реорганізації системи управління на таких територіях.

Вирішити ж питання реорганізації муніципального управління без зміни територіальної основи можна, застосувавши механізм добровільного об’єднання територіальних громад, передбачений однойменним Законом України «Про добровільне об'єднання територіальних громад». Законом врегульовані відносини щодо зміни системно-структурної організації місцевого самоврядування, порядку ліквідації чинних та формування нових муніципальних органів об'єднаних територіальних громад, вирішення питань матеріально-фінансової основи, бюджетування, державної підтримки добровільного об’єднання територіальних громад. Водночас таке об'єднання, як зазначено в ч. 3 ст. 4 названого Закону, не приводить до зміни правового статусу адміністративно-територіальних одиниць.

Тому застосування будь-якого із чинних законодавчих механізмів має опосередкований та половинчатий характер. Це свідчить про те, що забезпечити розв'язання питань адміністративно-територіального устрою через застосування положень i порядків, передбачених земельним або муніципальним законодавством, неможливо, необхідне ухвалення спеціального закону про адміністративно-територіальний устрій України. Безумовно, це твердження загальновідоме, але з року в рік воно, на жаль, не втрачає своєї актуальності.

По-п'яте, невирішеними залишаються питання правового забезпечення системи належного державного нагляду за законністю рішень та діяльності органів місцевого самоврядування. Реалізація конституційної реформи в частині внесення змін до р. VII Конституції України «Прокуратура», у результаті чого органи прокуратури були позбавлені функції загального нагляду, і незавершеність конституційної реформи щодо децентралізації влади, якою передбачалося введення інституту префектів, призвели до відсутності ефективної системи державного нагляду за законністю муніципальної діяльності ${ }^{19}$.

\footnotetext{
${ }^{19}$ Про внесення змін до Конституції України (щодо правосуддя) : Закон України від 2 червня 2016 р. № 1401-VIII. Відомості Верховної Ради України. 2016. № 28. Ст. 532.
} 
Отже, системне оновлення конституційно-правового i законодавчого регулювання відносин у сфері місцевого самоврядування має започаткувати новий етап у формуванні та здійсненні муніципальної політики й одночасно стати важливим кроком на шляху реалізації реформи територіальної організації влади.

\section{3. Проблеми формування і реалізації регіональної політики держави}

Сьогодні багато завдань запровадження реформи територіальної організації влади перебувають у площині регіональної політики держави. Без їх вирішення неможливо як забезпечити подальший розвиток місцевого самоврядування, так і підвищити ефективність децентралізаційних процесів. Тому ми всіляко підтримуємо визначений урядом України курс на регіональний розвиток і подальшу децентралізацію.

Серед нереалізованих напрямів Концепції реформування місцевого самоврядування та територіальної організації влади в Україні варто особливо наголосити на таких:

1. Концепція передбачала вимогу утворення виконавчих органів обласних і районних рад та розподілу повноважень між ними шляхом внесення відповідних змін до Конституції України. Однак і досі ситуація незмінна - районні й обласні ради позбавлені можливості формувати власні виконавчі органи та забезпечувати самостійно здійснення повноважень місцевого самоврядування. У зв'язку із цим на обласному рівні продовжується по суті втручання держави в питання місцевого самоврядування, оскільки функції виконавчих органів регіонального рівня залишаються за місцевими державними адміністраціями.

Теза про потребу інституційних перетворень на районному та регіональному рівнях набуває, на жаль, уже аксіоматичного характеру. Необхідність створення виконавчих органів районних і обласних рад, як i запровадження інституту префектів, визнано на всіх рівнях політичної організації держави та підтримано на міжнародному рівні. Останнім часом, відклавши на невизначений час ухвалення конституційного законопроекту щодо децентралізації влади та, відповідно, закону про префектів, цей напрям реформи вийшов 3 поля зору вищих органів державної влади. Але до нього варто повернутися.

I цього потребує муніципальна практика. Поруч із необхідністю забезпечення європейських стандартів організаційної автономії місцевого самоврядування процеси децентралізації, розширення кола делегованих органам місцевого самоврядування державних повноважень одночасно виявили й проблеми організації ефективного контролю за здійсненням таких повноважень, що зумовлені наявною прогалиною ефективного 
державного контролю за законністю діяльності органів та посадових осіб місцевого самоврядування. Відсутність дієвої, нормативно визначеної організаційно-правової системи такого контролю свідчить не про максимальну автономію місцевого самоврядування, а, імовріно, про перекладення повної відповідальності за соціально-економічне забезпечення та розвиток територіальних громад на муніципальні органи.

2. Потребує взаємоузгодження й оновлення законодавча база регіональної політики. Ухвалені закони України «Про стимулювання розвитку регіонів» ${ }^{20}$ та «Про засади державної регіональної політики» ${ }^{21}$, заклавши засади регіонального розвитку, водночас виявляються малодієвими, більшість їхніх положень так і не запрацювали. На особливу увагу заслуговують такі напрями, як стратегічне планування та фінансові механізми регіонального розвитку. Організаційно-правова модель «спочатку - проекти, потім - гроші» за непередбачуваності результатів відбору й обсягів фінансування фактично призводить до гальмування розроблення та подання проектів.

3. Потребує активізації потенціал Державного фонду регіонального розвитку. Він має спрямовуватися не на вирішення поточних фінансових проблем, а на перспективне інвестування в соціально-економічне зростання регіонів та громад. Енергозабезпечення, водопостачання, дошкільна та загальна середня освіта, благоустрій населених пунктів, охорона здоров'я, дорожньо-транспортна інфраструктура, сільськогосподарська діяльність, індустріальні й інноваційні парки тощо це ті основні сфери, в яких розробляються відповідні інвестиційні програми та проекти. Усього із 2015 р. $з$ усіх областей України подано станом на 28 лютого 2019 р. 18619 проектів, на загальну суму 2647263 494,394 грн ${ }^{22}$.

Проте істотно знижує ефективність цього інституційного механізму стимулювання регіонального розвитку наявна на сьогоднішній день практика непрогнозованого формування ДФРР, адже, незважаючи на встановлені Бюджетним кодексом України нормативи (не менше 1\% прогнозованого обсягу доходів загального фонду проекту Державного бюджету України на відповідний бюджетний період), відповідні суми зазнають коригування в межах бюджетного процесу ${ }^{23}$. Так, систематично

\footnotetext{
${ }^{20}$ Про стимулювання розвитку регіонів : Закон України від 8 вересня 2005 р. № 2850-IV. Biдомості Верховної Ради Украӥни. 2005. № 51. Ст. 548.

${ }^{21}$ Про засади державної регіональної політики : Закон України від 5 лютого 2015 р. № 156-VIII. Відомості Верховної Ради України. 2015. № 13. Ст. 90.

22 Державний фонд регіонального розвитку. URL: http://dfrr.minregion.gov.ua/Projects-list.

23 Бюджетний кодекс України від 8 липня 2010 р. № 2456-VI. Відомості Верховної Ради Украӥни. 2010. № № 50-51. Ст. 572.
} 
(з ухвалення Закону України «Про Державний бюджет України на 2016 р.» $\mathrm{i}$ до чинного бюджетного закону) зупиняється дія ч. 1 ст. $24^{1}$, якою передбачено мінімальний розмір ДФРР. Постає питання, навіщо державі брати на себе зобов'язання, а потім кожного року фактично відмовлятися від нього? Варто чітко закріпити фінансові гарантії державного стимулювання регіонального розвитку - воно має бути стабільним i передбачуваним.

4. Не запрацювали повною мірою агенції регіонального розвитку. Активна організаційно-правова взаємодія обласних рад, місцевих органів виконавчої влади й агенцій допоможе реалізувати потенціал регіонів, використати їхні конкурентні переваги, зміцнити інфраструктурний та людський потенціал регіонів, створити нові точки соціально-економічного зростання.

5. Потребує вдосконалення механізм моніторингу й оцінки результативності реалізації державної регіональної політики. Передбачена відповідною Методикою, затвердженою постановою Кабінету Міністрів України від 21 жовтня 2015 р. № 856, система показників щорічного моніторингу й оцінювання проводиться за 64 показниками (індикаторами) $^{24}$. Проте їх система не є достатньою і не використовує всі необхідні можливості. За оцінювання процесу здійснення відповідних заходів поза увагою залишаються результати, які характеризують не тільки результативність, але й ефективність регіональної політики, ступінь досягнення соціально значущих цілей і виконання завдань цієї політики.

6. Не можна залишити поза увагою і проблеми районування регіонів. Незважаючи на значні недоліки діючого районного поділу, районування забезпечує територіальний поділ праці в межах регіону та формування галузей господарської спеціалізації окремих територій, що безпосередньо впливає на стан соціально-економічного розвитку територій.

На необхідність законодавчої регламентації порядку вирішення питань адміністративно-територіального устрою, включаючи питання утворення, ліквідації районів, встановлення і зміни їхніх меж, нами вже зверталася увага. У цьому контексті маємо наголосити на отму, що хибним вважаємо шлях окремого законодавчого врегулювання порядку утворення, ліквідації районів, за відсутності загального закону, в якому мають визначатися порядок та повноваження відповідних органів державної влади щодо вирішення питань адміністративно-територіального устрою.

Важливим завданням регіонального напряму реформи територіальної організації влади стає оптимальне укрупнення наявних районів на підставі

\footnotetext{
24 Про затвердження Порядку та Методики проведення моніторингу та оцінки результативності реалізації державної регіональної політики : постанова Кабінету Міністрів України від 21 жовтня 2015 р. № 856. Офіиійний вісник України. 2015. № 88. Ст. 2926.
} 
законодавчо визначених критеріїв. Так, Концепцією реформування місцевого самоврядування та територіальної організації влади в Україні передбачено, що як концептуальні засади моделювання районів мають використовуватися такі критерії: обгрунтованість територіальної основи, іiі сучасність; здатність забезпечити доступність та належну якість публічних послуг, що надаються органами місцевого самоврядування та місцевими органами виконавчої влади, за наявності необхідної для цього ресурсної бази; наявність належних матеріальних, фінансових та організаційних умов для забезпечення здійснення органами місцевого самоврядування районного рівня власних i делегованих повноважень, перелік яких пропонується істотно розширити; забезпечення професійності надання публічних послуг та наявність висококваліфікованого кадрового складу районних органів публічної влади; оптимізація податкової бази, що дасть змогу забезпечити виконання органами місцевого самоврядування районного рівня власних повноважень 3 урахуванням об'єктивних критеріїв фінансування державою делегованих повноважень; уніфікованість стандартів надання публічних послуг та співмірність нормативів бюджетної забезпеченості жителів районів.

Крім того, потребує чіткого розмежування компетенція базового, районного й обласного рівнів місцевого самоврядування. Лише чітке визначення предметної підвідомчості кожного рівня місцевих рад та їхніх виконавчих органів надасть правове підгрунтя для ефективного функціонування, перерозподілу та делегування повноважень у межах системної організації місцевого самоврядування. Особлива увага має бути приділена тим галузям та сферам публічно-владного управління, що зорієнтовані на посилення соціально-економічної спроможності громад, а також створення сприятливих умов життєзабезпечення людини, зокрема, сферам управління земельними та природними ресурсами, соціального обслуговування, охорони здоров'я та освіти.

У сучасних умовах системного реформування територіальної організації влади оновлення регіональної політики - це важливий крок у напрямі підвищення ефективності соціально-економічної політики, оптимізації механізму надання публічних послуг, економії державних та місцевих ресурсів. Зміцнення правового статусу регіонів, оновлення системноструктурної організації публічної влади на регіональному рівні, перерозподіл функціонально-компетенційної сфери зі збільшенням владних можливостей регіональних властей - це ті вектори перетворень, які в Свропі дістали назву «новий регіоналізм» ${ }^{25}$ і які в Україні мають дістати належне правове забезпечення.

\footnotetext{
25 Бодрова I.І., Любченко П.М. Європейський досвід удосконалення місцевого самоврядування. Харків : Оберіг, 2012. С. 23.
} 


\section{ВИСНОВКИ}

Концепція реформування місцевого самоврядування та територіальної організації влади в Україні стала першим за роки незалежності України документом, що заклав науково-методологічну основу цілеспрямованого, системного та комплексного реформування адміністративно-територіального устрою, місцевого самоврядування й організації державної влади на територіальному рівні. Незважаючи на завершення встановлених строків реалізації, багато передбачених цим документом напрямів та заходів реформ залишаються нереалізованими. Регулятивний потенціал Концепції ще не вичерпаний, тому доцільним вбачається продовження термінів іiі дії й активізація діяльності із законодавчого забезпечення реформ.

Без перебільшення ролі правового впливу на суспільні процеси можна констатувати, що норма права в сучасній державі дозволяє оптимально проводити масштабні перетворення. В останні роки державою рішучо здійснюються системні зміни у сфері територіальної організації влади. Водночас потужною силою продовження реформ має стати ухвалення конституційного закону щодо децентралізації влади й ухвалення на його основі низки законів, які мають забезпечити необхідну та достатню правову основу для інституційних, функціональних, процедурнопроцесуальних перетворень у сфері територіальної організації влади.

Системно оновлюючи механізм здійснення публічної влади, реформуючи її територіальну організацію, розширюючи правоможливості місцевого самоврядування, здійснюючі рішучі кроки на шляху децентралізації влади, Україна впевнено йде до моделі європейської, сильної, ефективної, сервісної держави, де головною цінністю та мерилом державної політики виступає людина, іiї права та законні інтереси. Якісне ж оновлення правової політики держави має сприяти впровадженню європейських стандартів у даній сфері й одночасно стати чинником розвитку української державності, забезпечення іiї життєздатності й усталеності в умовах соціально-економічних викликів XXI ст.

\section{АНОТАЦІЯ}

Стаття присвячена аналізу стану правового забезпечення формування та реалізації реформи територіальної організації влади в Україні. У державі накопичилося багато доктринальних і практичних проблем, які стосуються правових аспектів територіальної організації влади, серед них нереалізованість реформи адміністративно-територіального устрою, незавершеність реалізації муніципальної реформи на засадах субсидіарності, повсюдності та спроможності місцевого самоврядування, обмеженість реформи регіонального рівня організації влади в інституційних та 
функціональних аспектах реалізації. Охарактеризовано концептуальні основи реформи територіальної організації влади в Україні, визначено роль i значення Концепції реформування місцевого самоврядування та територіальної організації влади в Україні як концептуально-методологічної основи системної модернізації територіальної організації влади в іiі адміністративно-територіальному, муніципальному та регіональному аспектах реформування. Визначено здобутки та проблемні питання формування та реалізації муніципально-правової політики держави, перспективи іiі вдосконалення, серед яких пожвавлення законодавчого забезпечення реформи, правове забезпечення адміністративно-територіальної реформи, ухвалення законів у сфері партисипативної демократії, закріплення державних зобов'язань щодо матеріально-фінансового забезпечення реалізації муніципальними органами делегованих повноважень, інституціоналізація механізму державного нагляду за законністю діяльності органів місцевого самоврядування й інші. Виокремлено нагальні завдання формування і реалізації регіональної політики держави. Особлива увага приділена тим із них, які відповідають загальноєвропейським тенденціям «нового регіоналізму»: інституційним та функціонально-компетенційним перетворенням у системно-структурній організації публічної влади на регіональному рівні, модернізації районування регіонів, удосконаленню стратегічного планування та стимулювання регіонального розвитку, механізму моніторингу й оцінки результативності реалізації державної регіональної політики. Вирішення означених завдань сприятиме впровадженню європейських стандартів у сфері територіальної організації влади та моделі сильної, ефективної, сервісної держави.

\section{ЛІТЕРАТУРА}

1. Бодрова І.І., Любченко П.М. Європейський досвід удосконалення місцевого самоврядування. Харків : Оберіг, 2012. 64 с.

2. Бюджетний кодекс України від 8 липня 2010 p. № 2456-VI. Відомості Верховної Ради України. 2010. № № 50-51. Ст. 572.

3. Гетьман А.П. Концептуальні засади модернізації конституційної моделі територіального устрою України Вісник Конституиійної Асамблеї. 2013. № 1. С. 325-330.

4. Державний фонд регіонального розвитку. URL: http://dfrr.minregion.gov.ua/Projects-list.

5. Додатковий протокол до Європейської хартії місцевого самоврядування про право участі у справах місцевого органу влади. URL: https://zakon.rada.gov.ua/laws/show/994_946. 
6. Свропейська хартія місцевого самоврядування : міжнародний документ від 15 жовтня 1985 p. URL: http://zakon2.rada.gov.ua/laws/show/ 994_036.

7. Крусян А.Р. Сучасний український конституціоналізм. Київ : Юрінкомінтер, 2010. 558 с.

8. Малько А.В. Теория правовой политики. Москва : Юрлитинформ, 2012. $328 \mathrm{c}$.

9. Нерсесянц В.С. Процессы универсализации права и государства в глобализирующемся мире. Государство и право. 2005. № 5. С. 38-47.

10. Новак А.О. Конституційно-правове регулювання здійснення органами місцевого самоврядування делегованих повноважень органів виконавчої влади в Україн : дис. ... канд. юрид. наук: 12.00.02. Харків, 2017. $241 \mathrm{c}$.

11. Об'єднані територіальні громади. URL: decentralization.gov.ua/ gromada.

12. Питання передачі земельних ділянок сільськогосподарського призначення державної власності у комунальну власність об'єднаних територіальних громад : розпорядження Кабінету Міністрів України від 31 січня 2018 р. № 60-p. URL: https://zakon.rada.gov.ua/laws/show/60-2018$\% \mathrm{D} 1 \% 80$.

13. Про внесення змін до Конституції України (щодо децентралізації влади) : проект закону України від 1 липня 2015 р. № 2217. URL: http://w1.c1.rada.gov.ua/pls/zweb2/webproc4_1?pf3511=55812.

14. Про внесення змін до Конституції України (щодо правосуддя) : Закон України від 2 червня 2016 р. № 1401-VIII. Вiдомості Верховної Ради Украӥни. 2016. № 28. Ст. 532.

15. Про добровільне об’єднання територіальних громад : Закон України від 5 лютого 2015 р. № 157-VIII. Відомості Верховної Ради України. 2015. № 13. Ст. 91.

16. Про засади державної регіональної політики : Закон України від 5 лютого 2015 р. № 156-VIII. Відомості Верховної Ради України. 2015. № 13. Ст. 90.

17. Про затвердження Порядку та Методики проведення моніторингу та оцінки результативності реалізації державної регіональної політики : постанова Кабінету Міністрів України від 21 жовтня 2015 р. № 856. Офіційний вісник України. 2015. № 88. Ст. 2926.

18. Про План законодавчого забезпечення реформ в Україні : постанова Верховної Ради України від 4 червня 2015 р. № 509-VIII. Biдомості Верховної Ради України. 2015. № 31. Ст. 297. 
19. Про співробітництво територіальних громад : Закон України від 17 червня 2014 р. № 1508-VII Відомості Верховної Ради Украӥни. 2014. № 34. Ст. 1167.

20. Про стимулювання розвитку регіонів : Закон України від 8 вересня 2005 р. № 2850-IV. Відомості Верховної Ради України. 2005. № 51. Ст. 548.

21. Про схвалення Концепції реформування місцевого самоврядування та територіальної організації влади в Україні : розпорядження Кабінету Мінстрів України № 333-р від 1 квітня 2014 р. Офіиійний вісник України. 2014. № 30. Ст. 18.

22. Реєстр договорів про співробітництво територіальних громад. URL: http://www.minregion.gov.ua/wp-content/uploads/2019/02/reestr27.02.2019.pdf.

23. Фінансова децентралізація: експерти розповіли про результати 2018 p. та перспективи 2019 p. URL: https://decentralization.gov.ua/news/ 10670?fbclid=IwAR0F89YRsn9N_Elc_wJAU86V9gkyGhO8Ly_YvnG9nuQytlcAQa_QLEShig.

24. Шемшученко Ю.С., Батанов О.В., Крусян А.Р. Конституційний процес в Україні та світовий досвід конституціоналізму. Київ : Юридична думка, 2014. 262 с.

\section{Information about author:} Bodrova I. I.,

Ph. D., Associate Professor, Deputy Director of Scientific Research Institute of State Building and Local Government of National Academy of Law Sciences of Ukraine 80, Chernyshevska str., Kharkiv, 61057, Ukraine 